\title{
Soil Organic Carbon in Godech Municipality, Western Bulgaria
}

\author{
By Borislav Grigorov ${ }^{1}$, Assen Assenov ${ }^{1}$
}

\begin{abstract}
The current study aims at examining soil organic carbon levels at the territory of Godech Municipality - one of the municipalities of Sofia Province, located in the western part of Bulgaria. The investigation includes information about some of the latest global studies, regarding soil organic carbon, including those, conducted on Bulgarian territory. Soil organic carbon plays a key role in overall carbon sequestration and it plays a key role for sustainable development. A basis of the study is the investigation of Hengl et al. (2017) who created a global soil grids at $250 \mathrm{~m}$ resolution. Their datasets consist of prediction data about carbon contents in $\mathrm{g}$ per $\mathrm{kg}$ at the following depths: $0 \mathrm{~cm}, 5$ $\mathrm{cm}, 15 \mathrm{~cm}, 30 \mathrm{~cm}, 60 \mathrm{~cm}, 100 \mathrm{~cm}$ and $200 \mathrm{~cm}$. This data is analyzed and developed for the purposes of the current study. Generally, soil organic carbon contents in Godech Municipality decrease from north to south, with the largest carbon pool in Berkvoska Mountain. There is an increase of carbon stocks from subsoil to topsoil, which is consistent with other results. The outcomes of the study prove to be successful and they can be applied in other investigations of this subject.
\end{abstract}

Keywords: carbon sequestration, soil organic carbon, sustainability

\section{Introduction}

Investigations, focusing on carbon sequestration, are increasing by the minute. This subject is gaining international recognition and is becoming more and more popular among scientific teams throughout the world. Carbon sequestration is considered as an essential process for climate change mitigation, therefore it is a key element for the promotion of the principles of sustainability. Soil is being acknowledged as the largest terrestrial carbon pool by various authors, including Stockmann et al. (2013), Scharlemann et al. (2014) and Ngaba et al. (2019), thus soils on worldwide scale are playing a major role in carbon sequestration and soil organic carbon is a key player for soil carbon sequestration. Its role is widely recognized and is acknowledged by UN's Sustainable development goals, together with the international "4 per 1000" initiative, governed by Soil for Food Security and Climate. It has been launched by the French Ministry of Agriculture at the United Nations Framework Convention for Climate Change: Conference of the Parties (UNFCCC COP 21) in Paris. The main aim, as showed by its title, is to increase worldwide soil organic carbon stocks by $0.4 \%$ each year. There is a number of scientific studies, published in the last decade, acknowledging the importance of soil organic carbon for overall carbon sequestration. The current investigation does not aim at deciphering, which are the most influential of them, however, the significance of these papers is an indisputable fact. They include the studies 
of Olson (2014) who attempted to define the meaning of soil carbon sequestration, Sommer \& Bossio (2014), Hoyle et al. (2016) who investigated agricultural territories in Australia, Wiesmeier et al. (2016) who also studied croplands, but in Germany. Zhang et al. (2017), Ma et al. (2018) and Lei et al. (2019) conducted experiments at Chinese territory. Mureva et al. (2018) collected soil samples from South Africa, the study of Ghimire et al. (2019) was performed in Oregon, USA and Iizumi, \& Wagai (2019) focused on the investigation of droughts. Last, but not least, Sugihara et al. (2019) did field experiments in Cameroon.

Investigations, based on carbon and its association with soil, are not a new topic in Bulgarian science, as well. Almost a decade ago Rodeghiero et al. (2011) included four sampling sites from Bulgaria in their study about ecosystems in the Mediterranean. Then in 2014 Tsolova et al. conducted a study of the carbon stocks in Technosols. Dimitrova et al. (2015) studied carbon storages in Yundola, Georgi Damyanovo and Berkovski Balkan. Nedkov et al. (2016, 2017) also conducted research on carbon stocks and finally, Zhiyanski and coauthors (2015, 2016 a,b, 2020) investigated the carbon pool in Western Rhodopes, Beklemeto and other key areas in the country.

\section{Materials and Methods}

The study area - Godech Municipality is located in the western part of Bulgaria and covers a territory of around 374 square kilometers (Fig. 1). It is a part of Sofia Province and consists of one town - Godech and 19 other villages. The main town is located in the valley of Nishava River and is landlocked between the mountains of Vidlich, Ponor and Chepan. Berkovska Mountain to the northwest and Vuchibaba are other mountains in the municipality. The climate is temperate continental. Other rivers, apart from Nishava River, are Visochitsa, Shumska and Zabardska - the last two are tributaries of Nishava River.

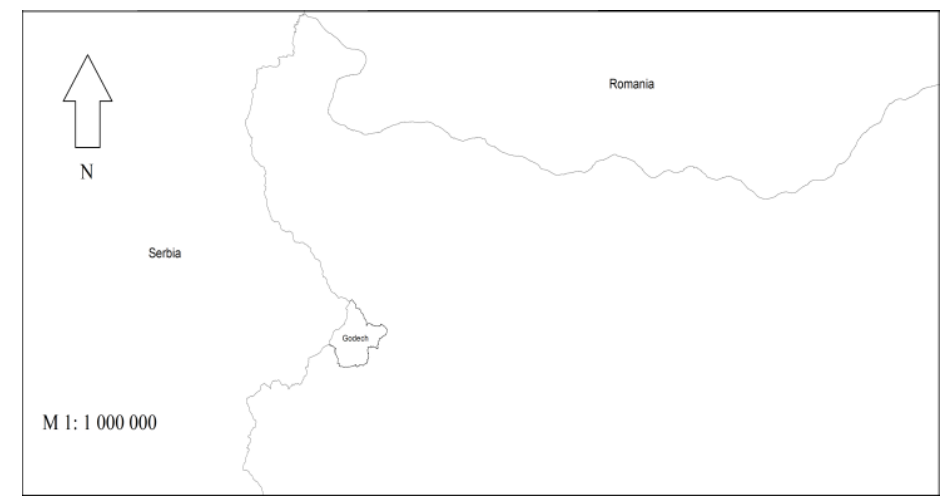

Figure 1. Location of Godech Municipality.

A cornerstone of the current investigation is the study of Hengl et al. (2017) who created global soil grids at $250 \mathrm{~m}$ resolution that are available for downloaded at https://soilgrids.org/. The main author, Tomislav Hengel is working at a non-profit organization, named International Soil Reference Information Center (ISRIC), mainly 
funded by the Dutch government. ISRIC developed a Global Soil Information system entitled "SoilGrids". "SoilGrids" are created to generate predictions on a global scale about several soil properties, including organic carbon and the current paper uses its latest version (a previous version deals with a resolution of $1 \mathrm{~km}$ ). For the purposes of the current study, seven datasets were downloaded, containing information about soil organic carbon content (fine earth fraction) in $\mathrm{g}$ per $\mathrm{kg}$. These datasets consist of information about carbon contents at the following depths: $0 \mathrm{~cm}, 5 \mathrm{~cm}, 15 \mathrm{~cm}, 30 \mathrm{~cm}, 60 \mathrm{~cm}, 100 \mathrm{~cm}$ and $200 \mathrm{~cm}$. This data was processed and analyzed for the purposes of the current investigation and the comparative method is applied in order to get better results.

\section{Results and Discussion}

The outcomes of the study are presented in the following lines. As for soil organic carbon stocks at $0 \mathrm{~cm}$ depth (Fig. 2 (left)), it can be argued that data is showing increase of the values from south to north. The highest values can be observed in Berkovska Mountain, located in the northwestern corner of Godech Municipality, and soil organic carbon storages at the area are reaching $264 \mathrm{~g}$ per kg. Another territory with almost such high values is locked between the villages of Gubesh and Gintsi at the central part of the municipality. The lowest soil organic carbon contents are located to the south and southwest, where they are as low as $28 \mathrm{~g}$ per $\mathrm{kg}$ near the villages of Stanintsi and Murgash.

Soil organic carbon contents at $5 \mathrm{~cm}$ depth (Fig. 2 (right)) are different from those at $0 \mathrm{~cm}$, but they also follow the same pattern of increase of contents from south to north. Yet soil organic carbon stocks at $5 \mathrm{~cm}$ are lower than those at $0 \mathrm{~cm}$. Once more, the values are highest in Berkovska Mountain to the northwest where soil organic carbon contents reach $133 \mathrm{~g}$ per $\mathrm{kg}$. The lowest values of $26 \mathrm{~g}$ per $\mathrm{kg}$ can be found to the northwest of the village of Varbnitsa and to the north of the village of Vradlovtsi to the west.
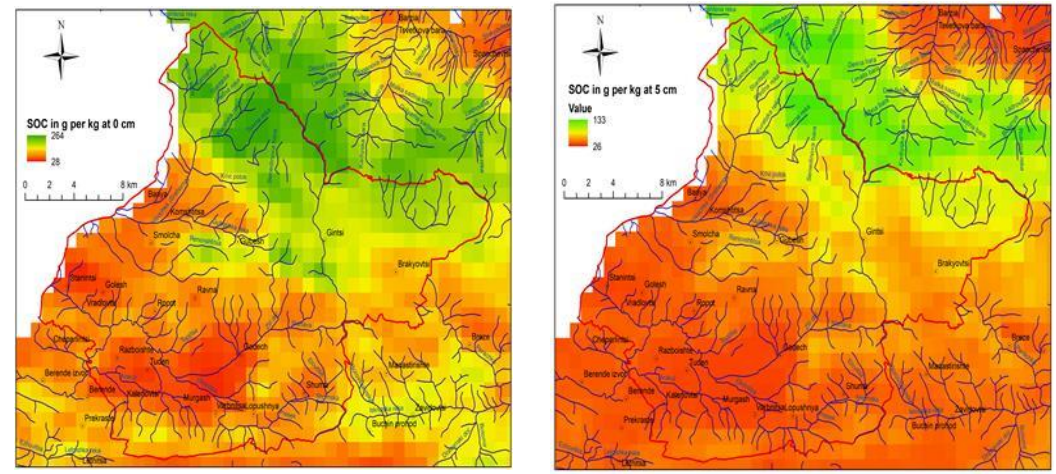

Figure. 2. Soil organic carbon in $\mathrm{g}$ per $\mathrm{kg}$ at $0 \mathrm{~cm}$ (left) and $5 \mathrm{~cm}$ depth (right)

The values at $15 \mathrm{~cm}$ depth (Fig. 3 (left)) again show the distinctive pattern with a decrease of the stocks from north to south. The highest values once more are at Berkovska Mountain and they are reaching $74 \mathrm{~g}$ per kg, while they are as low as $16 \mathrm{~g}$ per $\mathrm{kg}$ to the north of the villages of Varbnitsa and Murgash.

Data for twice as lower depth $-30 \mathrm{~cm}$ display the same pattern (Fig. 3 (right)). The 
lowest values for soil organic carbon are $9 \mathrm{~g}$ per $\mathrm{kg}$ and are located mainly to the south and the highest are only $45 \mathrm{~g}$ per $\mathrm{kg}$ and can be found in the north.
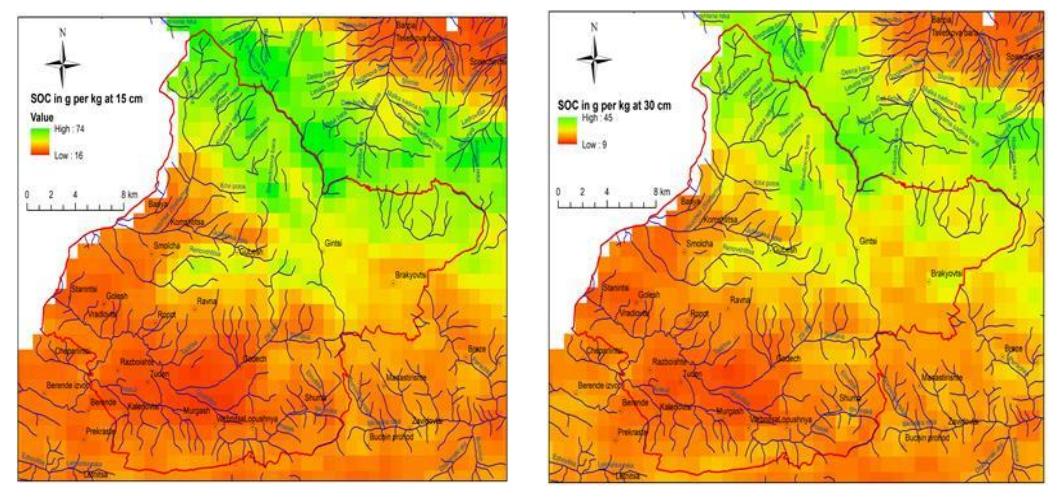

Figure. 3. Soil organic carbon in g per $\mathrm{kg}$ at $15 \mathrm{~cm}$ (left) and $30 \mathrm{~cm}$ depth (right)

The next examined depth is $60 \mathrm{~cm}$ and data here again is showing a downward decrease, compared to the previous results (Fig. 4 (top left)). The lowest value is $6 \mathrm{~g}$ per $\mathrm{kg}$, while the highest is $30 \mathrm{~g}$ per kg, again situated at the same areas.

The last two depths are $100 \mathrm{~cm}$ (Fig. 4 (top right)) and $200 \mathrm{~cm}$ (Fig. 4 (bottom)). The lowest and highest values are $4 \mathrm{~g}$ per $\mathrm{kg}$ and $28 \mathrm{~g}$ per $\mathrm{kg}$ at $1 \mathrm{~m}$ and $3 \mathrm{~g}$ per $\mathrm{kg}$ and $27 \mathrm{~g}$ per $\mathrm{kg}$ at $2 \mathrm{~m}$. They are following the same geographical pattern with highest values to the north and lowest to the south.
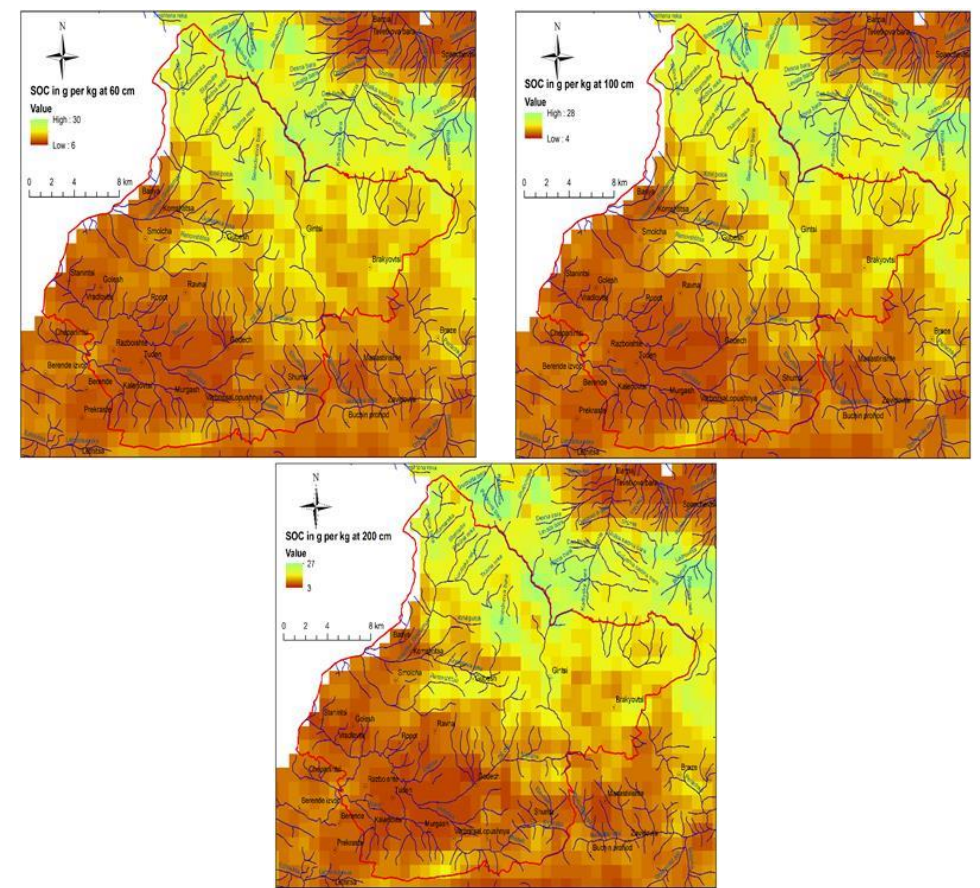

Figure. 4 Soil organic carbon in g per $\mathrm{kg}$ at $60 \mathrm{~cm}$ (top left), $100 \mathrm{~cm}$ depth (top right) $200 \mathrm{~cm}$ (bottom). 
The outcomes of the study show that soil organic carbon levels in Godech Municipality decrease with depth and from north to south. These lower values in subsoil, compared to topsoil are not the first in scientific literature and this data is consistent with the results of several other investigations. Freibauer et al. (2004) and ten years later Batjes (2014) argue that soil organic carbon stocks decrease with depth. During their study in Ireland, Torres-Sallan et al. (2017) also discuss a decline from topsoil to subsoil. Surely, it has to be clear that the results, concerning soil organic carbon storages in Godech Municipality, are based only on predictions and more data, including terrain sampling, is needed to prove or deny them. This is a weakness of the current research, yet the results are presenting a clear picture that can be applied by policy makers. The authors argue that Godech Municipality has a potential to increase its soil organic carbon pool if proper measures are adopted, including the application of no-till farming and the addition of biochar amendments. More should be done for the investigation of subsoil carbon levels, despite the fact that such focus has been a little neglected, as more experiments are aimed at topsoil. The fact that subsoil has a larger mass, thus storing more soil organic carbon, compared to topsoil, should be taken into account and Godech Municipality does not show different prospects.

\section{Conclusions}

The aim of the current study, focused at gathering and analyzing data about soil organic carbon contents in Godech Municipality, was accomplished. A strength of the work is the presence of enough data, allowing for making assumptions and there is sufficient information for seven different soil depths. The results show that soil organic carbon levels increase from south to north and from subsoil to topsoil, which is backed up by several other investigations worldwide. The highest soil organic carbon storages are at $0 \mathrm{~cm}$, reaching up to $264 \mathrm{~g}$ per $\mathrm{kg}$ in Berkovska Mountain to the northwest. Oppositely, their lowest levels are within $200 \mathrm{~cm}$ depth with $3 \mathrm{~g}$ per $\mathrm{kg}$, located to the south near the villages of Varbnitsa and Murgash. A weak point of the investigation is the lack of soil probes, which will provide more information about soil's carbon pool, so efforts should be aimed at acquiring such samples. Despite that more have to be done in order to improve the current investigation, it provides sufficient data for policy makers. The successful results may be applied as a basis for widening of the geographic range of the study in the neighboring municipalities, which will present a broader picture for soil organic carbon contents in Western Bulgaria.

\section{Acknowledgements}

This investigation was carried with the financial help of the national scientific programme "Young scientists and Postdoctoral students" for 2020.

\section{References}

Batjes, N. (2014). Total carbon and nitrogen in the soils of the world. Eur. J. Soil Sci. 65, 10-21.

Dimitrova, V., Lyubenova, M., Zhiyanski, M., Vanguelova, E. (2015). Roots biomass and carbon in representative Forest ecosystems in Bulgaria. J. Chem. Bio. Phy. Sci. Sec. D, Vol.5, No.2; 2090-2108. 
Ghimire, R., Bista, P., Machado, S. (2019) Long-term Management Effects and Temperature Sensitivity of Soil Organic Carbon in Grassland and Agricultural Soils. Sci Rep 9, 12151 doi:10.1038/s41598-01948237-7

Freibauer, A., Rounsevell, M., Smith, P., Verhagen, J. (2004). Carbon sequestration in the agricultural soils of Europe. Geoderma 122, 1-23.

Hengl, T., Mendes de Jesus, J., Heuvelink, G., Ruiperez Gonzalez, M., Kilibarda, M., Blagotić A. et al. (2017) SoilGrids250m: Global gridded soil information based on machine learning. PLoS ONE 12(2): e0169748. doi:10.1371/journal. pone.0169748

Hoyle, F., O'Leary, R., Murphy, D. (2016). Spatially governed climate factors dominate management in determining the quantity and distribution of soil organic carbon in dryland agricultural systems. Sci Rep 6, 31468 https://doi.org/10.1038/srep31468

Iizumi, T., Wagai, R. (2019). Leveraging drought risk reduction for sustainable food, soil and climate via soil organic carbon sequestration. Sci Rep 9, 19744 https://doi.org/10.1038/s41598-019-55835-y

Lei, Z., Yu, D., Zhou, F. et al. (2019). Changes in soil organic carbon and its influencing factors in the growth of Pinus sylvestris var. mongolica plantation in Horqin Sandy Land, Northeast China. Sci Rep 9, 16453 doi:10.1038/s41598-019-52945-5

Ma, J., Kang, F., Cheng, X., et al. (2018). Response of soil organic carbon and nitrogen to nitrogen deposition in a Larix principis-rupprechtii plantation. Sci Rep 8, 8638 doi:10.1038/s41598-01826966-5

Mureva, A., Ward, D., Pillay, T. et al. (2018). Soil Organic Carbon Increases in Semi-Arid Regions while it Decreases in Humid Regions Due to Woody-Plant Encroachment of Grasslands in South Africa. Sci Rep 8, 15506 doi:10.1038/s41598-018-33701-7

Nedkov, S., Zhiyanski, M., Nikolova, M., Gikov, A., Nikolov, P., Todorov, L. (2016). Mapping of carbon storage in urban ecosystems: a Case study of Pleven District, Bulgaria. Proceedings, Scientific conference Geographical aspects of land use and planning under climate change. Varshets, Bulgaria, 23. 09 - 25. 09. 2016 г. ISBN: 978-619-90446-1-2

Nedkov S., Zhiyanski, M., Dimitrov, S., Borisova, B., Popov, A., Ihtimanski, I., Yaneva, R., Nikolov, P., Bratanova-Doncheva, S. (2017). Mapping and assessment of urban ecosystem condition and services using integrated index of spatial structure. One Ecosystem 2: e14499. https://doi.org/10.3897/oneeco.2.e14499

Ngaba, M., Hu, Y., Bol, R. et al. (2019). Effects of land use change from natural forest to plantation on C, N and natural abundance of ${ }^{13} \mathrm{C}$ and ${ }^{15} \mathrm{~N}$ along a climate gradient in eastern China. Sci Rep 9, 16516 doi:10.1038/s41598-019-52959-z

Olson, K. (2014). Soil organic carbon sequestration, storage, retention and loss in U.S. croplands: Issues paper for protocol development. Geoderma, 195-196:201-206.

Rodeghiero, M. et al. (2011). Soil carbon in Mediterranean ecosystems and related management problems. Soil Carbon in Sensitive European Ecosystems: From Science to Land Management, First Edition. Robert Jandl, Mirco Rodeghiero and Mats Olsson.

Scharlemann, J., Tanner, E., Hiederer, R. , Kapos, V. (2014) Global soil carbon: understanding and managing the largest terrestrial carbon pool. Carbon Management, 5:1, 81-91, DOI: 10.4155/cmt.13.77.

Sommer, R. \& Bossio, D. (2014). Dynamics and climate change mitigation potential of soil organic carbon sequestration. J. Environ. Manage. 144, 83-87.

Stockmann, U. et al. (2013). The knowns, known unknowns and unknowns of sequestration of soil organic carbon. Agric. Ecosyst. Environ. 164, 80-99, https://doi.org/10.1016/j.agee.2012.10.001

Sugihara, S., Shibata, M., Mvondo Ze, A. et al. (2019). Forest understories controlled the soil organic carbon stock during the fallow period in African tropical forest: a ${ }^{13} \mathrm{C}$ analysis. Sci Rep 9, 9835 doi:10.1038/s41598-019-46406-2

Torres-Sallan, G., Schulte, R., Lanigan, G. et al. (2017). Clay illuviation provides a long-term sink for C sequestration in subsoils. Sci Rep 7, 45635 doi:10.1038/srep45635

Tsolova, V., Kolchakov, V., Zhiyanski, M. (2014). Carbon, Nitrogen and Sulphur Pools and Fluxes in Pyrite Containing Reclaimed Soils (Technosols) at Gabra Village, Bulgaria. Environ. Process. Springer International Publishing Switzerland. DOI 10.1007/s40710-014-0030-x

Wiesmeier, M., Poeplau, C. Sierra, C. et al. (2016). Projected loss of soil organic carbon in temperate agricultural soils in the $21^{\text {st }}$ century: effects of climate change and carbon input trends. Sci Rep 6, 32525 doi: $10.1038 / \operatorname{srep} 32525$ 
Zhang, F., Wang, Z., Glidden, S. et al. (2017). Changes in the soil organic carbon balance on China's cropland during the last two decades of the $20^{\text {th }}$ century. Sci Rep 7, 7144 doi:10.1038/s41598-017$07237-1$

Zhiyanski, M. (2015). Fine-root production and turnover based on 2-yr of sequential coring in four forest tree species in Bulgaria. Silva Balcanica, 16(1), 34-49.

Zhiyanski, M., Glushkova, M., Ferezliev, A., Menichetti, L., Leifeld, J. (2016a). Carbon storage and soil property changes following afforestation in mountain ecosystems of the Western Rhodopes, Bulgaria. iForest (early view). - doi: 10.3832/ifor1866-008

Zhiyanski, M., Gikov, A., Nedkov, S., Dimitrov, P., Naydenova, L. (2016b). Mapping Carbon Storage Using Land Cover/ Land Use Data in the Area of Beklemeto, Central Balkan. B. Koulov, G. Zhelezov (eds.), Sustainable Mountain Regions: Challenges and Perspectives in Southeastern Europe, Springer International Publisbing Switzerland, 53-65, DOI 10.1007/978-3-319-27905-3_4

Zhiyanski, M. (2020). Forest Ecosystems in Bulgaria Under Environmental Change-Carbon Sequestration Potential and Vulnerability Zones. In S. Nedkov et al. (eds.), Smart Geography, Key Challenges in Geography, Springer Nature Switzerland AG 2020, 417-441. https://doi.org/10.1007/978-3-03028191-5_31

https://soilgrids.org/ 